\title{
APPLICATIONS WITH AUGMENTED REALITY: INNOVATIVE TECHNOLOGY OF EDUCATIONAL PROCESS IN KAZAKHSTAN
}

Ayazhan Akhmetova Master student of the L.N.Gumilyov Eurasian National University, 010000, RK, Akmola region, Astana, Satpayev street, 2

Gulzhannat Dukembay

Candidate of Philology Sciences, Associate Professor of the Department of Theory and Practice of Foreign Languages of the L.N.Gumilyov Eurasian National University, 010000, RK, Akmola region, Astana, Satpayev street, 2

\begin{abstract}
The article deals with current issues of the use of augmented reality technology in education. Analyzed several examples of the use of technology in education. The principles of designing educational AR-applications are formulated, specific examples of AR-textbooks and applications are presented.
\end{abstract}

\begin{abstract}
АННОТАЦИЯ
В статье рассматриваются актуальные вопросы применения технологий дополненной реальности в образовании. Анализируются несколько примеров применения технологии в образовании. Формулируются принципы проектирования образовательных AR-приложений, представлены конкретные примеры AR-учебников и приложений.
\end{abstract}

Key words: AR-technology, augmented reality, education, books with augmented reality, augmented reality in education.

Ключевые слова: AR-технологии, дополненная реальность, образование, книги с дополненной реальностью, дополненная реальность в образовании

The technology of augmented reality in the field of education is mainly used as various kinds of simulators, as well as to demonstrate the processes, phenomena and objects, which are impossible or extremely difficult to show in reality. These can be the depths of the ocean or the expanses of space, the anatomy or the surface of another planet, the structure of molecules of chemicals and much more. As a rule, 
such demonstrations are embedded in the educational process and are carried out in short sessions. Simulators are used mainly in the field of medicine, physics, engineering.

In most cases, the result of the student's activity depends on the informativeness and fascination of the process of transferring knowledge, realizing the needs of students in cognition, and further focusing on the deepening of knowledge [1].

Technologies of augmented and virtual reality have significant didactic potential by virtue of providing visibility, which plays an important role in learning. Gesture control, motion tracking and face recognition enhance the capabilities of augmented and virtual reality technologies to create artificial social educational worlds. The boundaries between the real world and its virtual additions are gradually blurred. A huge advantage of using augmented reality technology is its visibility, informational completeness and interactivity [2].

Global companies are Google and Microsoft. The most famous and expected product based on augmented reality technology is Google Glass - augmented reality glasses. From Microsoft, you can select the sensor Kinect [3].

Existing companies in Kazakhstan engaged in research and development of applications based on augmented reality technology:

1. "AVR group" is a Kazakhstan hi-tech company that develops applications in the field of virtual, augmented reality and mixed reality, and also creates interactive VIP class presentations. The company implements technological solutions in the entertainment, advertising, educational, industrial, automotive and furniture sectors.

2. "Singularity lab" develops projects using virtual and augmented reality technology, as well as interactive media. The company relies on innovative technologies, concise design and intuitive user experience.

3. As part of a pilot project, "Center for Educational Programs" AEO NIS began developing digital resources for primary and primary schools together with foreign partners. Nowadays, two applications are available for download with the technology of augmented reality in mathematics and knowledge of the world. 
4. $\quad$ The publishing house "Big Dream" LLP for the first time in Kazakhstan began publishing books with augmented reality. The first edition of the book with augmented reality "Astana - the city of the future", issued by the publishing house, was sold in the amount of 5,000 copies.

5. "B2A" develops only mobile applications.

6. "Thousand" is an innovative team to develop augmented and virtual reality technology.

However not all of these companies develop applications and textbooks in the educational field. The main areas are industry and advertising, as they are the most profitable. Therefore, for the analysis, applications of three developers were selected: the "Center of educational programs" of the AEO NIS, publishing house of "Big Dream" and "B2A" (See Table 1).

Table 1 - Comparative analysis of applications

\begin{tabular}{|c|c|c|c|c|c|c|c|}
\hline $\begin{array}{l}\text { Develope } \\
\text { rs }\end{array}$ & Apps & $\begin{array}{l}\text { Language } \\
\mathrm{s}\end{array}$ & $\begin{array}{l}\text { Downloa } \\
\text { ds }\end{array}$ & $\begin{array}{l}\text { Rating on } \\
\text { Google } \\
\text { Play }\end{array}$ & $\begin{array}{l}\text { Rating on } \\
\text { AppStore }\end{array}$ & $\begin{array}{l}\text { Addition } \\
\text { al } \\
\text { material }\end{array}$ & Access \\
\hline \multirow[t]{2}{*}{$\begin{array}{l}\text { "CEP" } \\
\text { AEO NIS }\end{array}$} & $\begin{array}{l}\text { Математ } \\
\text { ика } 3 \\
\text { (AR) }\end{array}$ & $\begin{array}{l}\text { Kazakh } \\
\text { Russian }\end{array}$ & $500+$ & 5 & - & $\begin{array}{l}\text { Book } \\
\text { with QR- } \\
\text { code }\end{array}$ & Free \\
\hline & $\begin{array}{l}\text { Дүниета } \\
\text { ну } 3 \text { (AR) }\end{array}$ & $\begin{array}{l}\text { Kazakh } \\
\text { Russian }\end{array}$ & $500+$ & 5 & - & $\begin{array}{l}\text { Book } \\
\text { with QR- } \\
\text { code }\end{array}$ & Free \\
\hline \multirow{7}{*}{$\begin{array}{l}\text { Big } \\
\text { Dream }\end{array}$} & \multirow[t]{2}{*}{ Alippe } & \multirow[t]{2}{*}{ Kazakh } & \multirow[t]{2}{*}{$500+$} & \multirow[t]{2}{*}{3,9} & & Book & $4000 \mathrm{~T}$ \\
\hline & & & & & & App & Free \\
\hline & \multirow[t]{2}{*}{$\begin{array}{l}\text { Anatomy } \\
\text { AR book }\end{array}$} & \multirow{2}{*}{$\begin{array}{l}\text { Kazakh } \\
\text { Russian } \\
\text { English }\end{array}$} & \multirow[t]{2}{*}{$500+$} & \multirow[t]{2}{*}{3,7} & \multirow[t]{2}{*}{-} & Book & $4000 \mathrm{~T}$ \\
\hline & & & & & & App & Free \\
\hline & \multirow{2}{*}{$\begin{array}{l}\text { ABC AR } \\
\text { book }\end{array}$} & \multirow[t]{2}{*}{ Kazakh } & \multirow[t]{2}{*}{$50+$} & \multirow[t]{2}{*}{3} & \multirow[t]{2}{*}{ - } & Book & $4000 \mathrm{~T}$ \\
\hline & & & & & & App & Free \\
\hline & Extinct & Kazakh & $1000+$ & 3,4 & - & Book & $4000 \mathrm{~T}$ \\
\hline
\end{tabular}




\begin{tabular}{|l|l|l|l|l|l|l|l|}
\hline & $\begin{array}{l}\text { Giants } \\
\text { AR book }\end{array}$ & Russian & & & & App & Free \\
\hline B2A & $\begin{array}{l}\text { AR Card } \\
\text { Animal } \\
\text { Zoo }\end{array}$ & Russian & $1000+$ & 3,4 & - & - & Paid \\
\hline
\end{tabular}

Evaluation of user characteristics of the system showed an average degree, 3 points out of 5, satisfaction. The most popular applications by the number of downloads are "Extinct Giants AR book" and "AR Card Animal Zoo". The trilingual version is offered only by "Big Dream" publishing in the "Anatomy AR book" application. Almost all applications indicate in the brochures availability in the App Store, but when searching, the query does not produce a result. Almost all applications are free, but require the purchase of books.

The choice of developers of books with augmented reality can be argued by several advantages. First, it is a smooth transition from traditional textbooks to innovative ones. Secondly, the increasing popularity of books for young children who are used to playing with gadgets. And the last - this is a budget option, since these books are not expensive.

After analyzing Kazakhstan applications and books with augmented reality technology in education, we came to the conclusion that at the moment the choice is very small. Many developers and companies are just starting out. The main priority is profitability and demand in the market; therefore, applications for the smallest children with the alphabet and animals are mainly developed.

It is inappropriate to use these applications and books for lectures and seminars. When developing software solutions, one should be guided by the latest models of augmented reality equipment, the most eco-friendly and ergonomic for users. The hardware and software interface should be as simple as possible for users, especially for teachers.

Nevertheless, a review and analysis of augmented reality technology shows how this technology opens up new horizons in the field of education, providing the opportunity to supplement real objects with contextual information and visualization 
of educational material. It is clearly shown that the development of augmented reality technology in Kazakhstan is just beginning to gain momentum.

\section{References:}

1. Zaharova T.V., Kirgizova E.V., Basalaeva N.V. Methodical aspects of the use of an electronic textbook in teaching mathematics. Global'nyj nauchnyj potencial [Global scientific potential], 2013. no. 10(31), pp.18-21 (In Russian).

2. Petrova O.G. Augmented Reality for Education Available at: https://sites.google.com/site/relarn2010/glavnaa-stranica/tezisy-relarn-2013/petrovaoksana-dopolennaa-realnost-v-obrazovanii (accessed 18 February 2019)

3. Kravchenko YU.A., Lezhebokov A.A., Pashchenko S.V. Features of the use of augmented reality technology to support educational processes. Otkrytoe obrazovanie [Open education], 2014. no. 3 (104), pp. $49-54$ (In Russian).

4. Wu, H.-K., Lee, S., Chang, H.-Y., Liang, J.-C.: Current Status, Opportunities and Challenges of Augmented Reality in Education. Computers \& Education, 2013. no. 62, pp. 41-49. 